\title{
Assessment of Self-Care Behaviors, Self-Efficacy and Level of Physical Activity of Patients Undergoing Hemodialysis
}

Dr.Naglaa El sayed Mahedy, Dr. Mona Abed EL-Rhmen Mohamed, Soad Mansour El Sayed

Assistant professor of medical -Surgical department, Faculty of Nursing, Ain Shams

University., Lecturer of Medical Surgical Nursing, Faculty of Nursing, Port- said

University. Clinical instructor atDamietta Specialist hospital in Damietta

Governorate.

\begin{abstract}
Background: Hemodialysis (HD) patients' level of self-care behavior, self-efficacy and physical ability are important to manage their disease process and symptoms. Individuals who have adequate self-care and self-efficacy can adequately and appropriately meet their self-care needs, assume responsibility for their own health and can carry out their daily activities independently. Aim of the study: to assess self-care behaviors, self-efficacy and level of physical activity of patients undergoing Hemodialysis. Design: A descriptive exploratory research design was used in this study. Setting: This study was conducted at hemodialysis center at hospital affiliated to Ministry of Health (Port Said General Hospital) that sited in Port Said city. Sample: A purposive sample of (100) patients was recruited from rental units in Port-Said general hospital in a period of 6 months.. Results: More than half of the studied patients had inadequate physical activity level with percentage 53\%, inadequate self-care behavior with percentage (65\%) and moderate self-efficacy in $40 \%$ of them. Conclusion: Moreover, There is highly statistically significant positive correlation between all variables under the study. Recommendations: Teaching programstoimprove patients' knowledge and self-care practices to improve their health status and prevention of complications.
\end{abstract}

Key words: Self-care Behaviors, Self-Efficacy, Physical Activity, Hemodialysis. 


\section{INTRODUCTION}

End stage renal disease (ESRD) is "a progressive destruction of kidney function in which the body metabolism and water and electrolyte balance would be disturbed resulting in uremia" (Heidarzadeh et al., 2014). ESRD is a major public health problem, because of high morbidity and mortality as well as significant social and financial burden of this disease and its increasing prevalence (Pakpour et al., 2010).

The main treatment of ESRD is kidney transplantation; however in a world where there is still a significant shortage of renal donors, dialysis (hemodialysis (HD) or peritoneal dialysis (PD)) is by far the most common route of treatment (Atashpeikar et al., 2011). HD is an expensive and time consuming procedure that requires patients to follow a strict treatment schedule and fluid and dietary restrictions so it accompanies wide range of life style changes (Moattari et al., 2013). Additionally, this patients encounter many physical and psychosocial stresses including hypertension, lack of appetite, anemia, sexual disorders, reduced or loss of financial income, social isolation, loss of sense of security and dependence on caregivers (Heidarzadeh et al., 2014; Mahmoud,2015).

Self-care has played a role in nursing since of Florence Nightingale. As early as 1859 , Nightingale saw basic individual hygiene and environmental forces as instrumental determinants of individual and societal health. These values have been the guiding principles of public health nursing for years. Similarly, self-care as the basis of a nursing theory developed in the 1950 s by Dorothea Orem, and has guided the many nursing curricula that have existed since that time (Takeuchi et al.,2013).

Furthermore, self-care is conscious and continuous practice and in accordance with regulatory needs of individuals. Given that patients undergoing hemodialysis are dependent for a life time on a particular device or technique to preserve their life and have numerous worries about self-care, and also doubts about their ability to perform daily activities and normal life (Eylem and Mollaoge, 2012). Hemodialysis (HD) patients' self-care is important to their ability to manage their disease process and symptoms. Self-care behaviors include consuming an appropriate diet, taking medications regularly, limiting fluid intake, and many other activities to help them cope with symptoms and stress. When the self-care is inadequate serious complications can develop. (Atashpeikar et al.,2011). 
Physical illnesses followed by psychiatric disorders are common. so, Dialysis and kidney failure patients need emotional support to cope with the current situation. People who have high psychological and social support can more effectively adapt to stressful life events (Poorshaban, 2011). When the patient starts dialysis treatment, his life will be thoroughly changed, he should attend dialysis session regularly, use prescribed drugs, and modify anything he eats or drinks. The frequency and duration of dialysis is one of the stressful factors for patients on hemodialysis that affect the area of their mental, social problems and their efficacy (Burdmann, 2014).

Sabha and Achterberg (2013) stated that, Self-efficacy aids in the adoption and maintenance of health promoting behaviors as well as in the control of risky health habits. Individuals with high self-efficacy overcome obstacles by improvement of selfmanagement skills and stay the course in the face of difficulties. Whereas those of low sense of efficacy do not try to adopt healthy practices and if they do try, they quickly abandon their efforts if success is not immediately achieved.

According to Avesani et al.,(2012) physical activity is currently being increasingly recognized as an important strategy for disease prevention and disease management, it does not automatically correspond to all patients being regularly physically active. Physical inactivity is believed to be common in many patients, but it is unclear how much physical activity patients actually perform, which patients are meeting physical activity guidelines, and which factors are related to physical activity.

Patients who come to the dialysis clinic for the first time are understandably anxious and upset about needing dialysis, a procedure that will dominate their life until they get a new kidney. Teaching patients what to expect during dialysis, walking them through the process, explaining how much time dialysis will take and answering any questions is part of the hemodialysis nurse's job. For example, patients must learn to evaluate their dialysis access port for redness, drainage or other signs of infection (Kaba et al., 2011) 


\section{Significant of the study:}

Hemodialysis (HD) patients' level of self-care behavior and self-efficacy are important to their ability to manage their disease process and symptoms. When the level of selfcare is inadequate serious complications can develop. Individuals who have adequate self-care and self-efficacy can adequately and appropriately meet their self-care needs, assume responsibility for their own health and can carry out their daily activities independent of others (Denyes et al., 2011).

Hemodialysis patient exposed to more of problem during his treatment, he/she had less power to doing his daily activity and sharing in more self-care needs. So, the hemodialysis effected on self-care behavior, self-efficacy view and level of physical activity for this patient who had long term hemodialysis treatment for this direction this study do. Therefore, the study was conducted to assess self-care behaviors, selfefficacy and level of physical activity of Patients undergoing hemodialysis.

\section{AIM OF THE STUDY:}

The aim of present study is to assess self-care behaviors, self-efficacy and level of physical activity of patients undergoing hemodialysis

\section{Objectives:}

1-Assessment of self-care behaviors for patients undergoing hemodialysis.

2-Assessmentof self-efficacy of patients undergoing hemodialysis.

3- Assessment of Level of physical activity of patients undergoing hemodialysis.

\section{- Research question}

1- what is the level of self-care behavior of patients undergoing hemodialysis?

2- What is the level of self-efficacy of patients undergoing hemodialysis ?3- what is the level of physical activity of patients undergoing hemodialysis? 


\section{- Operational definition}

Hemodialysis is an extracorporeal mechanical method of renal replacement for patients with ESRD using the principle of osmosis, diffusion, and ultrafiltration to replace some of the kidney's major function.

Self-car behavior is an active participation in own health care, it is about learning what to do to take care of on self and when to decide to ask for help.

Self-efficacy: self-efficacy is mediated by a person's beliefs or expectations about his/her capacity to accomplish certain tasks successfully or demonstrate certain behaviors.

Physical activity level: refer to exercise training or unstructured movement throughout the day.

\section{SUBJECTS AND METHOD:}

\section{Research Design:}

A descriptive exploratory research design was used in this study.

\section{Study Setting}

This study was conducted at hemodialysis center at hospital affiliated to Ministry of Health (Port Said General Hospital) that sited in Port Said city, in the period of being October 2015 till end of March 2016

\section{Study Subjects:}

A purposive sample of (100) patients was recruited from renal units in Port-Said general hospital.

\section{Inclusion criteria of the patient:}

-Willingness to participated in study.

-Ability to read.

-Had normal cognitive function.

\section{Exclusion criteria:}

-Immobility patient.

-Spinal cord injury, muscular dystrophy patient.

-Stroke, rheumatoid arthritis patient.

-Patient how having hearing or eyesight problem. 


\section{Tools for data collection}

Four tools were used to collect data of the presents study as follows:

\section{Tool I: A Structured interviewing questionnaire}

This interviewing questionnaire was developed by the researcher to assess patients' demographic data and patients' medical history (present, past and family history).

\section{Tool (II) :Self-care behavior assessment questionnaire:}

This tool adopted from (Lutlf, 2007) to assess self-care behavior for hemodialysis patients. The questionnaire translated into Arabic language and retranslated to English to ensure the right meaning of the tool.

It was consisted of five main parts:
A) - Part 1: it was used to assess self-care behavior regarding personal hygiene.
B) - Part 2: it was used to assess self-care behavior regarding nutrition.
C) - Part3: it was used to assess self-care behavior regarding to elimination and urination.

D) - Part 4: it was used to assess self-care behavior related to arterial venous access (shunt).

E) - Part 5: it was used to assess patient regarding to his/her and taking prescribed medication.

\section{Scoring system:-}

This tool scoring (Self-care behavior assessment questionnaire) adopted from (Lutlf, 2007), all question scored (0 to 3). The scores were distributed on four responses as the following; (never $=0$, rarely $=1$, sometime $=2$, all days $=3$ )

Also, regarding to the adequate Self-care behavior level,it was considered that:

- $\quad<60 \%$ of total grades was considered inadequate Self-care behavior level

- $\quad \geq 60 \%$ of total grades was considered adequate Self-care behavior level.

\section{- Tool III: Hemodialysis Self-efficacy scale:}

This tool adopted from (Lin et al., 2012) to assess general sense of perceived self efficacy with the aim in mind to predict coping with daily effort after experiencing all kind of stressful life events added to difficulties of the diseases .This scale consisted from 25 items. 


\section{Scoring system}

The scale had score from ( 0 to 5 ), it was (none of the time $=0$, little of time $=1$, some of time $=2$, the good bit of the time $=3$, most of time $=4$, all of the time $=5$ ). The zero score refers to low patient efficacy degree but five score refers to high patient's efficacy degree. Total scoring defined to three degree in this consider (less than $30 \%$ is low self-efficacy, between $30 \%$ to $70 \%$ is moderated self-efficacy and more than $70 \%$ is high self-efficacy) (Lin et al., 2012). The scale translated into Arabic language and the retranslated to English to ensure the right meaning of the tool.

\section{Tool (IV): Human Activity Profile (HAP) questionnaire:}

This tool adapted form (Johansen et al., 2001), to assess level of physical activity in end stage renal failure patient .The Human Activity Profile (HAP) is designed to assess general physical activity. It consists of list of 20 activities ranked in ascending order according level of energy required to perform the activity. This tool modified according to the hemodialysis patient and translated into Arabic language and the retranslated to English to ensure the right meaning of the tool.

\section{Scoring system}

This tool take three score (zero $=$ refused done, $1=$ stopped to done, $2=$ done).

Also, regarding to the adequate Self-care behavior level, it was considered that:

- $<60 \%$ of total grades was considered inadequate physical level

- $\geq 60 \%$ of total grades was considered adequate physical level

\section{(II) OPERATIONAL DESIGN}

The operational design included preparatory phase, content validity, pilot study and fieldwork.

\section{The Preparatory Phase}

It included reviewing of literatures related to the problem and theoretical knowledge of various aspects of the problem using books, articles, periodicals and magazines to develop tools for data collection. 


\section{Content Validity}

The tool was tested for its content validity, comprehensiveness and applicability by 9 expertise's of professors and lecturers from the Medical-Surgical Department; Faculty of Nursing, Port Said University and El Mansoura University and from medicine department, Faculty of Medicine, Al-Azhar University who revised the tools and modifications were done according to their opinion.

\section{Pilot Study}

Pilot study was conducted on $10 \%$ of subjects. It was done to test the clarity and practicality of the tools, the results of the data obtained from the pilot study helped in modification of the tools; items were corrected or added as needed. Accordingly, modifications were done and the final form was developed. The results from the pilot study were excluded from the main statistical sample.

\section{Reliability of the study tool:}

Cronbach alpha coefficient was used to assess the internal consistency of the tool. Self- care behavior regarding personal hygiene tool was (.84), Self- care behavior regarding Venus access care tool was (.89), self-efficacy scale (.93) and level of physical activity tool was (0.82).

\section{Field work:}

The actual field work was started during period from the beginning of October (2015) to the end of March (2016) for data collection. The researcher visited the hospital (the hemodialysis unit in Port Said general hospital), two days weekly (at morning and afternoon) shifts (no night shift in this hospital for hemodialysis patient) to collect the data by using previous tools. The purpose of the study was explained by the researcher to the patients under hemodialysis who agreed to participate and who had the above mention inclusion criteria in the study. The researcher identified herself to the patient, her jobs and purpose of the study. When patient agreed, the researcher first collect data regarding patient's demographic data, then ask about medical history, after that, the researcher assessed self-care behavior, self-efficacy and then the level of physical activity by using the previous study tools which took about 15 to 20 minutes for each single tool. The researcher collected data in the mooring shift in some weeks or in 
afternoon shift in the other weeks. The researcher changed the two days weekly to meet new cases and can meet all patients in the hemodialysis unit.

\section{III) ADMINISTRATIVE DESIGN:}

A formal letter from the Dean or Vice Dean for higher education of the Faculty of nursing Port Said University was submitted the aim of the study and procedures were explained to directors of Port Said General Hospital to attain their cooperation.

An official permission for data collection was obtained from directors of Port Said General Hospital and (director of hemodialysis unit) Hospital in Port Said City.

\section{Ethical Considerations:}

The agreement for participation of the subjects was taken after aims of the study have been explained to them. A verbal informed consent was obtained from the patients to ensure willingness to engage in the study after explaining its purpose. They were informed about their rights to refuse or withdraw at any time with no consequences on their care. The study interventions could not have any harmful effect on participants and they were assured that the information collected would be treated confidentially and used for the research purpose only.

\section{Statistical design:}

The collected data were categorized, revised, stored, tabulated and analyzed using number and percentage distribution. Statistical analysis was done by computer using Statistical Package of Social Science program (SPSS) package version 16. Proper statistical tests were used to determine whether there was a significant statistical difference between variables of the study.

\section{RESULT:-}

Table (1): shows the distribution of hemodialysis patients' demographic characteristics. The study result shows that, $45 \%$ of studies patients had age $\geq 50$ years and $55 \%$ of studied patients were female. Concerning to marital status, $74.0 \%$ of them were married. About the educational level, $33.0 \%$ had secondary level of education and $30 \%$ of them were illiterate, Regarding to the number of family member $49 \%$ their family member about 4-6. 
Table (2): Represents that,53\% of the studies patient had inadequate physical level with percentage 53\% and with (Mean \pm SD) equals to (44.71 \pm 12.04$)$, Regarding to self-care behaviors, $65 \%$ of the studies patients had inadequate self-care behavior and with (Mean \pm SD)equals $(84.31 \pm 2.31)$, Moreover, regarding self-efficacy, $40 \%$ of them had moderate self-efficacy and only $29 \%$ of them had high self-efficacy with total (Mean \pm SD ) equals $(75.62 \pm 13.90)$.

Table (3): This table reveals that, there is no significant statistic relation between total self-efficacy level and level of physical activity that chi-square $\mathrm{X}^{2}(1.16)$ and $\mathrm{P}$ value be (.560). While, there is high significant relation between total self-efficacy level and total self-care that $\mathrm{X}^{2}$ chi-square be (8.63) and $\mathrm{P}$ value (.013).

Table (4): shows that, there is highly statistically significant positive correlation between all variables under the study.

Table (5): This table reveals that, there is statistically significant relation between the level of physical activity and marital status and between the level of physical activity and number family member with $\mathrm{p}(0.020-0.015)$. While there is no statistically significant relation between level of physical activity and both level of education and gender, with $(\mathrm{P}<0.05)$.

Table (6): shows that, there is statistically significant relation between self-care behavior and demographic characteristics of studies patients (level of education, marital status and gender) with $\mathrm{p}$ value (0.037-0.026-0.008). While, there is no statistically significant relation between self-care behavior and family member number.

Table (7): Illustrates that, there is statistically significant relation between selfefficacy and level of education, family number and marital status with value less than 0.05 . While there is no statistically significant relation between self-efficacy and gender where the $\mathrm{p}$ value 0.670 . 
Table (1): Number and percentage distribution of the studied patient according to their demographic characteristics. $(\mathrm{N}=100)$.

\begin{tabular}{|c|c|c|}
\hline Item & $\begin{array}{l}\text { Frequency } \\
n=100\end{array}$ & Percentage $\%$ \\
\hline $\begin{array}{l}\text { Age } \\
20-30 \text { years } \\
\geq 35-50 \text { years } \\
\geq 50 \text { years }\end{array}$ & $\begin{array}{l}15 \\
40 \\
45\end{array}$ & $\begin{array}{l}15 \% \\
40 \% \\
45 \% \\
\end{array}$ \\
\hline $\begin{array}{l}\text { Sex } \\
\text { Male } \\
\text { Female }\end{array}$ & $\begin{array}{l}45 \\
55\end{array}$ & $\begin{array}{r}45.0 \\
55.0 \\
\end{array}$ \\
\hline $\begin{array}{l}\text { Level of Education: } \\
\text { Illiterate } \\
\text { Read and write } \\
\text { Secondary } \\
\text { University }\end{array}$ & $\begin{array}{l}30 \\
26 \\
33 \\
11\end{array}$ & $\begin{array}{l}\frac{30.0}{26.0} \\
\frac{33.0}{11.0}\end{array}$ \\
\hline $\begin{array}{l}\text { Marital Status: } \\
\text { Single } \\
\text { married } \\
\text { Divorced } \\
\text { Widowed }\end{array}$ & $\begin{array}{l}8 \\
74 \\
6 \\
12 \\
\end{array}$ & $\begin{array}{l}8.0 \\
\frac{74.0}{6.0} \\
12.0\end{array}$ \\
\hline $\begin{array}{l}\text { Number of Family member } \\
1-3 \\
4-6 \\
7 \text { or more }\end{array}$ & $\begin{array}{l}34 \\
49 \\
17\end{array}$ & $\begin{array}{l}34.0 \\
49.0 \\
17.0\end{array}$ \\
\hline
\end{tabular}


Table (2): Number and percentage distribution of total Physical level, Self-care behaviors and Self-efficacy among the studies hemodialysis patient: $N=100$

\begin{tabular}{|c|c|c|}
\hline Items & No & $\%$ \\
\hline Physical level: & & \\
\hline Inadequate & 53 & $\underline{53.0}$ \\
\hline Adequate & 47 & 47.0 \\
\hline Mean \pm SD & \multicolumn{2}{|c|}{$44.71 \pm 12.04$} \\
\hline \multicolumn{3}{|l|}{ Self-care behaviors: } \\
\hline Inadequate & 65 & $\underline{65.0}$ \\
\hline Adequate & 35 & 35.0 \\
\hline Mean \pm SD & \multicolumn{2}{|c|}{$84.31 \pm 2.31$} \\
\hline \multicolumn{3}{|l|}{ Self-efficacy: } \\
\hline Low & 31 & 31.0 \\
\hline Moderate & 40 & $\underline{40.0}$ \\
\hline High & 29 & 29.0 \\
\hline Mean \pm SD & \multicolumn{2}{|c|}{$75.62 \pm 13.90$} \\
\hline
\end{tabular}

Table (3): Relation between total self-efficacy level and self-care behaviors, Physical activity level among the studied patients. $\mathrm{N}=100$

\begin{tabular}{|c|c|c|c|c|c|c|c|c|}
\hline \multirow[t]{3}{*}{ Items } & \multicolumn{6}{|c|}{ Total self-efficacy level } & \multirow{3}{*}{$x^{2}$} & \multirow{3}{*}{ p-value } \\
\hline & \multicolumn{2}{|c|}{ Low } & \multicolumn{2}{|c|}{ Moderate } & \multicolumn{2}{|c|}{ High } & & \\
\hline & No & $\%$ & No & $\%$ & No & $\%$ & & \\
\hline Physical le & & & & & & & & \\
\hline $\begin{array}{l}\text { Inadequate } \\
\text { Adequate }\end{array}$ & $\begin{array}{l}18 \\
13\end{array}$ & 58.1 & $\begin{array}{l}22 \\
18\end{array}$ & $\begin{array}{l}55.0 \\
45.0\end{array}$ & $\begin{array}{l}13 \\
16\end{array}$ & $\begin{array}{l}44.8 \\
55.2\end{array}$ & 1.16 & .560 \\
\hline Self-care bc & & & & & & & & \\
\hline $\begin{array}{l}\text { Inadequate } \\
\text { Adequate }\end{array}$ & $\begin{array}{l}25 \\
6\end{array}$ & 80.6 & $\begin{array}{l}27 \\
13\end{array}$ & $\begin{array}{l}67.5 \\
32.5\end{array}$ & $\begin{array}{l}13 \\
16\end{array}$ & $\begin{array}{l}44.8 \\
55.2\end{array}$ & 8.63 & .013 \\
\hline
\end{tabular}


Table (4): Correlation coefficient between self-care ,self-efficacy and level of physical activity: $n=100$

\begin{tabular}{|c|c|c|c|c|}
\hline Items & & Self-efficacy & $\begin{array}{l}\text { Physical } \\
\text { activity }\end{array}$ & $\begin{array}{l}\text { Self-care } \\
\text { behavior }\end{array}$ \\
\hline self-efficacy & $\begin{array}{l}\text { Pearson Correlation } \\
\text { Sig. }\end{array}$ & 1 & $\begin{array}{l}.102 \\
.313\end{array}$ & $\begin{array}{l}.290^{* *} \\
.003\end{array}$ \\
\hline Physical activity & $\begin{array}{l}\text { Pearson Correlation } \\
\text { Sig. }\end{array}$ & $\begin{array}{l}.102 \\
.313\end{array}$ & 1 & $\begin{array}{l}.307^{*} \\
.018\end{array}$ \\
\hline Self-care behavior & $\begin{array}{l}\text { Pearson Correlation } \\
\text { Sig. }\end{array}$ & $\begin{array}{l}.290^{* *} \\
.003\end{array}$ & $\begin{array}{l}.307^{*} \\
.018\end{array}$ & 1 \\
\hline
\end{tabular}

. Correlation is significant at the $* *(0.01)$ level.

Table (5): Relation between level of physical activity and demographic characteristics of studied patients. $\mathrm{N}=100$

\begin{tabular}{|c|c|c|c|c|c|c|}
\hline \multirow[t]{3}{*}{ Items } & \multicolumn{4}{|c|}{ Physical activity } & \multirow{3}{*}{$\mathbf{X}^{2}$} & \multirow{3}{*}{ p-value } \\
\hline & \multicolumn{2}{|c|}{ Inadequate } & \multicolumn{2}{|c|}{ adequate } & & \\
\hline & No & $\%$ & No & $\%$ & & \\
\hline $\begin{array}{l}\text { Level of Education: } \\
\text { Illiterate } \\
\text { Read and write } \\
\text { Secondary } \\
\text { university }\end{array}$ & $\begin{array}{l}20 \\
14 \\
14 \\
5\end{array}$ & $\begin{array}{l}37.7 \\
26.4 \\
26.4 \\
9.4\end{array}$ & $\begin{array}{l}10 \\
12 \\
19 \\
6\end{array}$ & $\begin{array}{l}21.3 \\
25.5 \\
40.4 \\
12.8\end{array}$ & 3.990 & .263 \\
\hline $\begin{array}{l}\text { Marital Status: } \\
\text { Single } \\
\text { married } \\
\text { Divorced } \\
\text { widowed }\end{array}$ & $\begin{array}{l}1 \\
44 \\
1 \\
7\end{array}$ & $\begin{array}{l}1.9 \\
83.0 \\
1.9 \\
13.2\end{array}$ & $\begin{array}{l}7 \\
30 \\
5 \\
5\end{array}$ & $\begin{array}{l}14.9 \\
63.8 \\
10.6 \\
10.6\end{array}$ & 9.824 & .020 \\
\hline $\begin{array}{l}\text { Family member number } \\
1-3 \\
4-6 \\
7 \text { or more }\end{array}$ & $\begin{array}{l}12 \\
28 \\
13\end{array}$ & $\begin{array}{l}22.6 \\
52.8 \\
24.5\end{array}$ & $\begin{array}{l}22 \\
21 \\
4\end{array}$ & $\begin{array}{l}46.8 \\
44.7 \\
8.5\end{array}$ & 8.376 & .015 \\
\hline $\begin{array}{l}\text { Gender: } \\
\text { male } \\
\text { female }\end{array}$ & $\begin{array}{l}25 \\
28\end{array}$ & $\begin{array}{l}47.2 \\
52.8\end{array}$ & $\begin{array}{l}20 \\
27\end{array}$ & $\begin{array}{l}42.6 \\
57.4\end{array}$ & .215 & .643 \\
\hline
\end{tabular}


Table (6): Relation between self-care behaviors and demographic characteristics.

\begin{tabular}{|c|c|c|c|c|c|c|}
\hline \multirow[t]{3}{*}{ Items } & \multicolumn{4}{|c|}{ Self-care behavior } & \multirow{3}{*}{$\mathbf{X}^{2}$} & \multirow{3}{*}{ p-value } \\
\hline & \multicolumn{2}{|c|}{ inadequate } & \multicolumn{2}{|c|}{ adequate } & & \\
\hline & No & $\%$ & No & $\%$ & & \\
\hline $\begin{array}{l}\text { Level of Education: } \\
\text { Illiterate } \\
\text { Read and write } \\
\text { Secondary } \\
\text { University }\end{array}$ & $\begin{array}{l}17 \\
17 \\
25 \\
6\end{array}$ & $\begin{array}{l}26.2 \\
26.2 \\
38.5 \\
9.2\end{array}$ & $\begin{array}{l}13 \\
9 \\
8 \\
5\end{array}$ & $\begin{array}{l}37.1 \\
25.7 \\
22.9 \\
14.3\end{array}$ & 4.125 & .037 \\
\hline $\begin{array}{l}\text { Marital Status: } \\
\text { Single } \\
\text { married } \\
\text { Divorced } \\
\text { widowed }\end{array}$ & $\begin{array}{l}5 \\
45 \\
6 \\
9\end{array}$ & $\begin{array}{l}7.7 \\
69.2 \\
9.2 \\
13.8\end{array}$ & $\begin{array}{l}3 \\
29 \\
0 \\
3\end{array}$ & $\begin{array}{l}8.6 \\
82.9 \\
0.0 \\
8.6\end{array}$ & 4.351 & .026 \\
\hline $\begin{array}{l}\text { Family member number: } \\
1-3 \\
4-6 \\
7 \text { or more }\end{array}$ & $\begin{array}{l}23 \\
32 \\
10\end{array}$ & $\begin{array}{l}35.4 \\
49.2 \\
15.4\end{array}$ & $\begin{array}{l}11 \\
17 \\
7\end{array}$ & $\begin{array}{l}31.4 \\
48.6 \\
20.0\end{array}$ & .392 & .822 \\
\hline $\begin{array}{l}\text { Gender: } \\
\text { male } \\
\text { female }\end{array}$ & $\begin{array}{l}23 \\
42\end{array}$ & $\begin{array}{l}35.4 \\
64.6\end{array}$ & $\begin{array}{l}22 \\
13\end{array}$ & $\begin{array}{l}62.9 \\
37.1\end{array}$ & 6.938 & .008 \\
\hline Total & 65 & 100.0 & 35 & 100.0 & & \\
\hline
\end{tabular}


Table (7): Relation between self-efficacy and characteristic of the studied patients.

\begin{tabular}{|c|c|c|c|c|c|c|c|c|}
\hline \multirow[t]{3}{*}{ Items } & \multicolumn{6}{|c|}{ Self-efficacy } & \multirow{3}{*}{$\mathbf{X}^{2}$} & \multirow{3}{*}{ p-value } \\
\hline & \multicolumn{2}{|c|}{ Low } & \multicolumn{2}{|c|}{ Moderate } & \multicolumn{2}{|c|}{ High } & & \\
\hline & No & $\%$ & No & $\%$ & No & $\%$ & & \\
\hline $\begin{array}{l}\text { Level of Education: } \\
\text { Illiterate } \\
\text { Read and write } \\
\text { Secondary } \\
\text { University }\end{array}$ & $\begin{array}{l}12 \\
9 \\
8 \\
2\end{array}$ & $\begin{array}{l}38.7 \\
29.0 \\
25.8 \\
6.5\end{array}$ & $\begin{array}{l}14 \\
11 \\
13 \\
2\end{array}$ & $\begin{array}{l}35.0 \\
27.5 \\
32.5 \\
5.0\end{array}$ & $\begin{array}{l}4 \\
6 \\
12 \\
7\end{array}$ & $\begin{array}{l}13.8 \\
20.7 \\
41.4 \\
24.1\end{array}$ & 11.66 & .047 \\
\hline $\begin{array}{l}\text { Family member nuI } \\
1-3 \\
4-6 \\
7 \text { or more }\end{array}$ & $\begin{array}{l}9 \\
13 \\
9\end{array}$ & $\begin{array}{l}29.0 \\
41.9 \\
29.0\end{array}$ & $\begin{array}{l}18 \\
18 \\
4\end{array}$ & $\begin{array}{l}45.0 \\
45.0 \\
10.0\end{array}$ & $\begin{array}{l}7 \\
18 \\
4\end{array}$ & $\begin{array}{l}24.1 \\
62.1 \\
13.8\end{array}$ & 7.90 & .059 \\
\hline $\begin{array}{l}\text { Marital Status: } \\
\text { Single } \\
\text { married } \\
\text { Divorced } \\
\text { Widowed }\end{array}$ & $\begin{array}{l}1 \\
20 \\
4 \\
6\end{array}$ & $\begin{array}{l}3.2 \\
64.5 \\
12.9 \\
19.4\end{array}$ & $\begin{array}{l}3 \\
33 \\
2 \\
2\end{array}$ & $\begin{array}{l}7.5 \\
82.5 \\
5.0 \\
5.0\end{array}$ & $\begin{array}{l}4 \\
21 \\
0 \\
4\end{array}$ & $\begin{array}{l}13.8 \\
72.4 \\
0.0 \\
13.8\end{array}$ & 10.26 & .014 \\
\hline $\begin{array}{l}\text { Gender: } \\
\text { male } \\
\text { female }\end{array}$ & $\begin{array}{l}16 \\
15\end{array}$ & $\begin{array}{l}51.6 \\
48.4\end{array}$ & $\begin{array}{l}17 \\
23\end{array}$ & $\begin{array}{l}42.5 \\
57.5\end{array}$ & $\begin{array}{l}12 \\
17\end{array}$ & $\begin{array}{l}41.4 \\
58.6\end{array}$ & .802 & .670 \\
\hline
\end{tabular}

\section{DISCUSSION:}

Chronic kidney failure has no cure, but treatment can help control signs and symptoms, reduce complications, and slow the progress of the disease (Mane, 2014). Hemodialysis is a treatment method which aims to remove accumulated metabolic waste products and to correct blood electrolyte composition by means of an exchange between patient's blood and a dialysate fluid miming normal extracellular fluid across a semi-permeable membrane (O'Callaghan, 2011; O'Hare et al.,2013).

Self-care is an active participation in patient own health care, it is about learning what to do to take care of own self and when to decide to ask for help (Lacy et al., 2012 ; William, 2013). Furthermore, the level of physical activity were alliterated due to pathophysiology of diseases moreover the patients had difficulties to perform activity needs also the patient self-efficacy were also affected. So that, the hemodialysis nurse had role to improve patient self-care behavior, self-efficacy and increase level of physical activity ( Perkins,2014). 
Regarding to demographic characteristics of studies patients, the present study revealed that, more than half of the patient were female, the majority of studied patient's age were above 50 years and about three quarter of studied patients were married. Also, the study showed near one third of studies patient were illiterate.

This result similar to Al-Garni, (2012) who mentioned in a study entitled (Assessment of Health-Related Quality of Life among End-Stage Renal Disease (ESRD) Adult Patients Undergoing Hemodialysis) that half of sample was females. In addition, the majority of the sample was married. Also the present study revealed educational level of studied patients was mainly illiterate. This result is inconsistent with Ivey and Lane (2011) found that two thirds of the studied sample was educated. This result indicate that educational level may have positive impact on patient's compliance and taking care of themselves.

As regarded to relation between level of physical activity and demographic characteristics, the study reveals that: there is statistically significant relation between the level of physical activity and marital status, also there is statistically significant relation between the level of physical activity and number of family members. This finding is contraindicating with Yaghmayi, (2009) who reported that chronic renal failure has mutual effects on physical, psychological and functional status of individuals which causes types of deprivation and lifestyle changes including financial problems, unemployment, change in familial roles, and more affected by demographic characteristic.

No statistically significant relation between level of physical activity and education and gender .This finding is not corroborated with a previous study by Johansen et al., (2012) who evaluated the low level of physical activity of 1547 patients with chronic renal failure. The study cited advanced age, female sex, diabetes, atherosclerosis, and low education level as variables associated with a low physical activity level.

Furthermore, according to relation between self-care behaviors and demographic characteristics the study asserted that there is statistically significant relation between self-care behavior and demographic characteristics (level of education, marital status and gender). This results similar to study by Soulmaz and Tahereh (2012) who stated that men had more self-care ability than women, males had higher educational level 
than women and since educated patients could better recognize their self-care needs, therefore it might be the explanation of this difference. The other effective factor in this regard as age Also, Atashpeikar et al. (2011) reported that patients who have higher educational level can help in better recognition of their self-care activity. Otherwise, Oshvandi, (2008) don't supported this finding, the self-care don't affect by marital status or gender and family member.

In this respect the study findings revealed that, there is no statistically significant relation between self-care behavior and family member number. This result consisted with Oshvandi, (2008) who find that the self-care don't affect by marital status or gender and family member. Meanwhile, this finding in same line with Gicabalaga, (2012) who study (self-efficacy and self-care management outcome among 50 patients undergoing Hemodialysis) reported that, family member number had more effected on patient hemodialysis self-care behavior.

The study result findings show that, there is statistically significant relation between self-efficacy and level of education, family number with renal failure and marital Status. In this relation between self-efficacy and this variables. This finding confirmed that, self-efficacy affected by some factors such as member of family and marital status. This results supported by Takeda, (2015) who reported relationship between perceived self-efficacy, coping behavior, demographic characteristic among junior patients who were hospitalized for renal disease and found that a positive correlation was found between self-efficacy and marital status. Meanwhile, this finding is not confirmed with Tang and Kwok. (2010) who found in his study that self-efficacy don't affected by family member and marital status.

On another hand, the study results reported that there is no statistically significant relation between self-efficacy and gender. This finding inconsistent with the study by Yesilbalkan et al.,(2009) in a study about self-efficacy of hemodialysis dialysis patients and found that, the men had higher self-efficacy than women.

On the basis of these results, there is no significant statistic relation between selfefficacy and level of physical activity, meanwhile, there is high significant relation between self-efficacy and total self-care. This finding similar to Smith et al., (2012); Zhuang, (2013) who indicated on kidney disease study that,patients with a high level 
of self-efficacy had better self-management, especially in the category of self-care, self-efficacy can help the patient to demonstrate self-management behaviors. Furthermore, this result is similar to Rahimi et al., (2014) found that there was a significant relation between level of self-care and self-efficacy, by increasing self care, self-efficacy is also increasing.

In the current study, there is highly statistically significant positive correlation between total variables of the study (self-care behavior, self-efficacy and level of physical activity. This positive correlation made them mined in to found the variables that had the upper hand to affect in two anther variables. This self-efficacy is more effected variables in my opinion.

\section{CONCLUSION:}

More than half of studied patients had inadequate physical level and about two third of them had inadequate self-care behavior. While, only less the one third of them had high self-efficacy. There is no significant statistic relation between total self-efficacy level and level of physical activity. However, there is high significant relation between self-efficacy and total self-care. Also, there is highly statistically significant positive correlation between all variables under the study.

\section{RECOMMENDATIONS:}

- Developing a system of periodical patients' evaluation to determine strategies of upgrading their knowledge and enhancing their needs.

- Encouraging patients to participated in training program to improve level of physical activity.

- Reapplication of the study on a large sample from different hospitals, as well as from different geographical area in Egypt to evaluate the effect of hemodialysis on self-care behavior and self-efficacy.

- Study of the impact of educational program for patients' undergoing hemodialysis to improve of self-efficacy and level of physical activity and its effect on quality of life of hemodialysis patients. 


\section{REFERENCE :}

Al-Garni., (2012):Assessment of Health- Related Quality of Life Among End-Stage. Journal of Caring Sciences, 2(5):33-35.

Atashpeikar S., Jalilazar T., Heidarzadeh M., (2011): Self-Care Ability in Hemodialysis Patients . Journal of Chronic renal failure, 8 (10):89-93.

Avesani CM, Trolonge S, Deleaval P, Baria F, Mafra D, Faxen-Irving G, et al., (2012): Physical activity and energy expenditure in haemodialysis patients: an international survey. Nephrology Dialysis Transplantation Journal, 27(6):233-238.

Burdmann EA.,(2014): Determinants of Compliance Behaviours among Patients Undergoing Hemodialysis in Malaysia. Journal Clinical Nursing, 7(8):413 - 462.

Denyes, M. J.,Cherneck D. E, GerdBekel, S., (2011): Self-care practice for hemodialysis patient. Nursing Science Quarterly Journal, 14 (6): 48-54.

Eylem B and Mollaoge., (2012): Self-care self-efficacy, depression, and quality of life among patients receiving hemodialysis in Taiwan. International Journal of Nursing Studies,3(9):245-251.

Gicabalaga A., (2012): Self-Efficacy and Self- Care Management Outcome of Chronic Renal Failure Patients. Asian scientific journal, 2 (2): 66

Heidarzadeh F.,EhagJ,Rahimi, A, Einollahi, B.,(2014): Introducation about progress of renal failure.Nursing Research Journal,9(7):201.

Ivey Dand Lane M. , (2011):Impact of chronic illness over the life span. international nursing studies journal,8 (2):45-56.

Johansen KL, Chertow GM, Kutner NG, Dalrymple LS, Grimes BA, Kaysen GA., (2012): Low level of self-reported physical activity in ambulatory patients new to dialysis. Kidney International Nursing Journal, 7(8):164-170.

Johansen, K., Painter, P., Kent-Braun, J., A.,Carey, S., Silva, M., et al., (2001): Validation Of Questionnaires To Estimate Physical Activity And Functioning In Endstage Renal Disease. Kidney International Journal, 59(3): 121-127. 
Kaba, E., Bellou, P., Iordanou, P., Andrea, S., Kyritsi, E., Gerogianni, G., Swigart, V., (2011): Self-efficacy in haemodialysis patients. British Journal of Nursing,32(14): 868-873.

Lin CC, Wu CC, Wu LM et al., (2012):Psychometric Evaluation Of An Instrument Of The Early Stage Chronic Kidney Disease Self-management. Journal of Clinical Nurse, 5(4): 128-134.

Lutlf, A., (2007): Assessment Self-care Practice Among Patient On Maintenance Hemodialysis. M. Sc.N Thesis Faculty Of Nursing Alexandria university,P.p.135-139.

Mahmoud y.,(2015): Effect hemodialysis on Health status of patient. journal of evaluation in clinical practice,67(34):22-34.

Meane A. , (2014): chronic renal failure Diseases. New England journal of medicine, $34(5): 123-130$.

Moattari, M. Ebrahimi, M. Sharifi, N. and Rouzbeh, J., (2013): The effect of empowerment on the self-efficacy, quality of life and clinical and laboratory indicators of patients treated with hemodialysis. Health Society Journal,3(5):66-70.

O'Callaghan C .,(2011) : Health Care Management Strategies Of Long-term Dialysis survivors. Journal Of Nephrology Nursing, 28(4): 385-394.

O'Hare AM, Tawney K, Bacchetti P, Johansen KL., (2013):Decreased survival among sedentary patients undergoing dialysis: results from the dialysis morbidity and mortality study wave. American Journal Kidney Diseases, 4(13):447-454.

Oshvandi KH., (2008): The effect of Self-care education in decreasing the problems of hemodialysis patients. Journal of Clinical Nursing, 11(5):100-110

Pakpour G., Beyramijam, M. and Naseri, O., (2010): renal failure diseases mortality and morbidity. Nursing practice Journal,3(6):88.

Perkins., (2014): Health beliefs and quality of life in end - stage renal disease. International Journal of Caring Sciences. 4 (3): 144. 
Poorshaban M., (2011):The effect of education diet on the severity of the physical problems and improve self-efficacy of CKD. .Nursing Research Journal,9(2):47-55.

Rahimi, F., Gharib, A., Beyramijam, M. and Naseri, O., (2014): Effect of self-care education on self-efficacy in patients undergoing hemodialysis. Life Science Journal, 11(9):50-59.

Sabha S and Achterberg., (2013): Health beliefs and quality of life in end stage renal disease. International Journal of Caring Sciences, 4 (3) :144-146

Smith, K., Coston, M., Glock, K., Elasy, T.A., Wallston, K.A., Ikizler, T.A., Cavanaugh, K.L., (2012): Patient perspectives on fluid management in with chronic kidney disease. Advances in Chronic Kidney Disease journal, 3 (7) 191-202.

Soulmaz and Taherehk., (2012):the effect of educational program on self care in hemodialysis patient. Amircal nephology journal,7(15):90-97.

Takeda, T., (2015):Self-Efficacy, Coping Behavior, and the Health Locus of Controlling Patient with Renal Disease. Nephrology Dialysis Transplant Journal,6(1):200-210.

Takeuchi E, Serufukeashugan, Rives T, Tyson J., (2013): The current state of nursing research focused on self-care. The Niigata Journal of Health and Welfare, 4 (20): 438-447.

Tang A and Kwork. L., (2010): Patients' priorities for health research: focus group study of patients with chronic kidney disease. Nephrology Dialysis Transplant journal, 2(3):32-34.

Yesilbalkan A,Jacsone F, Khost, A. Alavi., (2009):Assessment self-efficacy in hemodialysis patient. Nursing Research Journal, 9(2):160-170.

Ykoyama K., Court A, Lockwood C.,(2009):Factor affecting on self-efficacy. Nursing practice nursing Journal,6(4):77-82.

Zhuang, G., (2013): The condition and influencing factors of self-management in renal transplant recipients. School of Nursing, Fujian Medical University. Journal of Advanced Nursing, 9(3):204-209. 


\section{تقييم سلوكيات الرعاية والكفاءة الذاتية ومستوي النشاط البذني للمرضى الخاضعين للغسيل الكلوي}

\section{أ.م.د/ نجلاء السيد مهرى1،، د/منى عبدالرحمن محمد2، سعاد منصور السيد أحمد 3}

أستاذ مساعد بقسم التمريض الباطنيو الجر احيـ كليه التمريض - جامعه عين شمس ، مدرس التمريض الباطني و الجر احي- كليـة التمريـضـ- جـامعــة بـورسـيـد ، أخصائية تمريض بمستشفى دمياط التخصصي بمحافظة

$$
\text { دمياط }
$$

\section{الخلاصة}

المريض الذي يخضعلغسيل الكلى في حاجة الي تحسين مستوي الرعاية و الكفاءة الذاتية وذللك لمساعداته على التغلب على المرض و أعراضه. ان مريض الغسيل الكلوي يتعرض لمشاكل جسدية ونفسية عديدة، فذلك يجعلهيعتد على الآخرين في بعض أنشطة الرعاية الثخصية اليومية ، فان الأفر اد الذين لديهم القدرة على القيام بهذه الانشطة والكفاءة الذاتية الكافية يمكنه تلبية احتياجاتهم، وتحمل المسؤولية عن صحتهم ويمكن أن يؤدوا

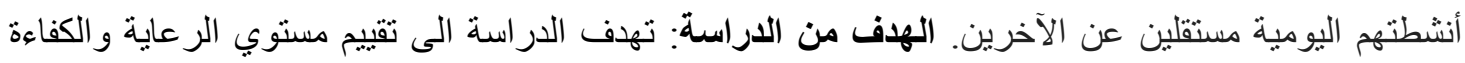
الذاتية ومستوي النشاط البدنى للمرضى الخاضعين للغسيل الكلوي .تصميم البحث : تم استخدام دراسة وصفية . مكان البحث: هذه الدر اسة تم تنفيذها في وحده غسيل الكلى فى مستشفى بورسعيد العام.عينه البحث:جميع مرضى الغسيل الكلوي الذين يترددوا على مركز الغسيل الذى تم ذكره خلال سته أثشهر. نتائج الدراسة: هنالك عدم كفاية في سلوك الرعاية الذاتية بنسبة (65\%) ومستوى الكفاءة الذاتية منوسطبنسبة 40٪. الخلاصة: هناك ارتباط إيجابي للغاية ذات دلالة إحصائية بين كل المتغير ات محل الدر اسة.التوصيات: توصى الدر اسة بعمل بر امج تعليمي

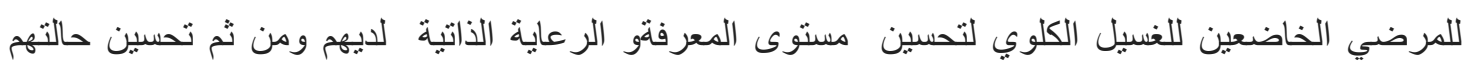

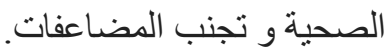

